
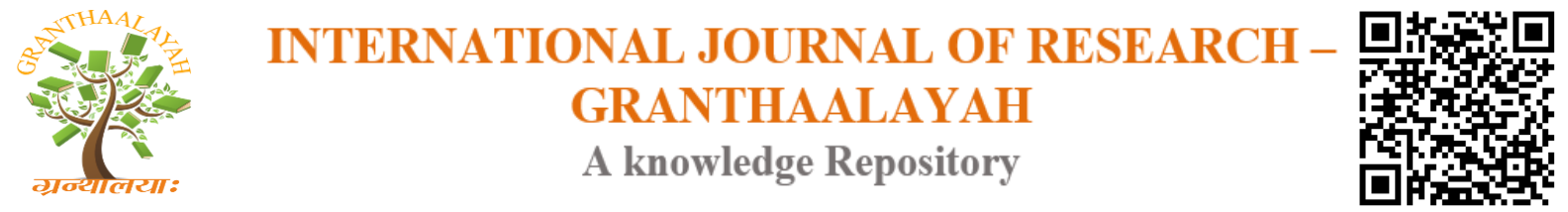

Management

\title{
GOODS AND SERVICES TAX: A STUDY ON ROAD MAP FOR 2017
}

\author{
Nidhi *1 \\ ${ }^{* 1}$ Assistant Professor in Commerce, Hindu Kanya P.G. Mahavidyala, Jind (HR), INDIA
}

DOI: https://doi.org/10.29121/granthaalayah.v4.i9.2016.2529

\section{ABSTRACT}

The paper covers the scope of GST and the history of the taxation system in India.

The word tax is derived from the Latin word 'taxare' meaning, to estimate. "A tax is not a voluntary payment or donation, but an enforced contribution, exacted pursuant to legislative authority" and is any contribution imposed by government whether under the name of toll, tribute, impost, duty, custom, excise, subsidy, aid, supply, or other name." Taxes in India are levied by the Central Government and the State Governments. Some minor taxes are also levied by the local authorities such as Municipality or Local Council. The paper consists of the demerits of existing taxation system, challenges and opportunities of the GST and the latest amendments with the road map for 2017. With the help of this paper we get the overview of the current amendments and the future efforts to be made in the implementation of GST.

Keywords:

GST, Sales tax, Excise Duty, Customs Duty, Road map.

Cite This Article: Nidhi, "GOODS AND SERVICES TAX: A STUDY ON ROAD MAP FOR 2017” International Journal of Research - Granthaalayah, Vol. 4, No. 9 (2016): 1-13.

\section{INTRODUCTION}

\section{HISTORY OF TAXATION}

The word tax is derived from the Latin word 'taxare' meaning, to estimate. "A tax is not a voluntary payment or donation, but an enforced contribution, exacted pursuant to legislative authority" and is any contribution imposed by government whether under the name of toll, tribute, impost, duty, custom, excise, subsidy, aid, supply, or other name." The first known system of taxation was in Ancient Egypt around 3000 BC - 2800 BC in the first dynasty of the Old Kingdom. Records from that time show that the pharaoh would conduct a biennial tour of the kingdom, collecting tax revenues from the people. Other records are granary receipts on limestone flakes and papyrus. Early taxation is also described in the Bible. In Genesis, it states "But when the crop comes in, gives a fifth of it to Pharaoh. The other four-fifths you may keep as seed for the fields and as food for yourselves and your households and your children." Joseph was telling the people of Egypt how to divide their crop, providing a portion to the Pharaoh. A 
share 3 of the crop was the tax. In India, the tradition of taxation has been in force from ancient times. It finds its references in many ancient books like 'Manu Smriti' and 'Arthasastra'. The Islamic rulers imposed jizya5. It was later on abolished by Akbar. However, Aurangzeb, the last prominent Mughal Emperor, levied jizya on his mostly Hindu subjects in 1679. Reasons for this are cited to be financial stringency and personal inclination on the part of the emperor, and a petition by the ulema.

The period of British rule in India witnessed some remarkable change in the whole taxation system of India. Although, it was highly in favor of the British government and its exchequer but it incorporated modern and scientific method of taxation tools and systems. In 1922, the country witnessed a paradigm shift in the overall Indian taxation system. Setting up of administrative system and taxation system was first done by the Britishers. Broadly, there are two types of Taxes viz. Direct and Indirect taxes. Taxes in India are levied by the Central Government and the State Governments. Some minor taxes are also levied by the local authorities such as Municipality or Local Council. The authority to levy tax is derived from the Constitution of India which allocates the power to levy various taxes between Centre and State.

\section{TAX STRUCTURE IN INDIA}

Taxes in India are levied by the Central Government and the State Governments. Some minor taxes are also levied by the local authorities such as Municipality or Local Council. The authority to levy tax is derived from the Constitution of India which allocates the power to levy various taxes between Centre and State.

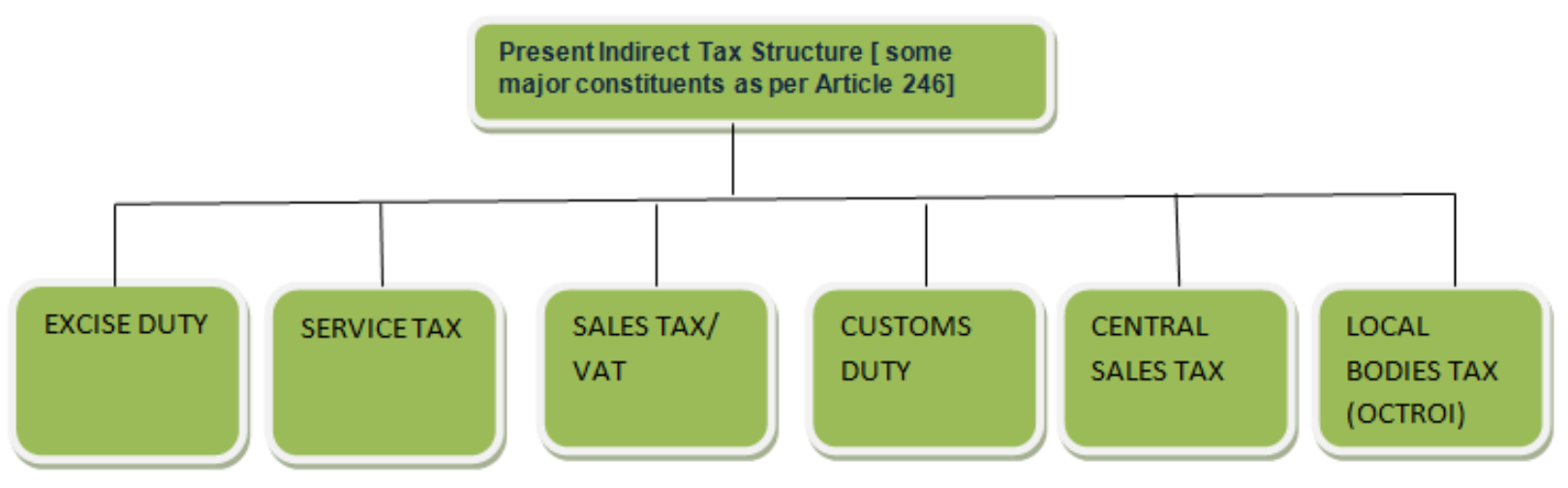

The various tax laws are levied and collected as follows:

\begin{tabular}{|llll|}
\hline Tax & $\begin{array}{l}\text { Taxable Event } \\
\text { Sanufacture of Goods in India CG }\end{array}$ & CG \\
& $\begin{array}{l}\text { (excluding goods manufactured in } \\
\text { SEZ in India) }\end{array}$ & CG \\
\hline Service Tax & $\begin{array}{l}\text { Provision of Service in Taxable CG } \\
\text { Territory }\end{array}$ & Sale of goods within the State & SG \\
\hline Customs Duty & $\begin{array}{l}\text { Import into India from a place CG } \\
\text { outside India or Export from India to }\end{array}$ & CG \\
\hline
\end{tabular}




\begin{tabular}{|c|c|c|}
\hline & a place outside India & \\
\hline Central sales Tax & $\begin{array}{ll}\text { Sale of goods Inter-State } & \text { CG } \\
\text { (i.e. from one State to another State) } & \end{array}$ & $\mathrm{SG}$ \\
\hline $\begin{array}{l}\text { Local } \quad \text { Body } \quad \text { Tax } \\
\text { (Entry } \\
\text { Tax/Octroi) }\end{array}$ & $\begin{array}{l}\text { Entry of goods to a State from a SG } \\
\text { place outside the State }\end{array}$ & SG \\
\hline
\end{tabular}

Where, $\mathrm{CG}=$ Central Government; $\mathrm{SG}=$ State Government

\section{Major milestones in Indirect Tax reform}

- 1974 Report of LK Jha Committee suggested VAT

- 1986 Introduction of a restricted VAT called MODVAT

- 1991 Report of the Chelliah Committee recommends VAT/GST and recommendations accepted by Government

- 1994 Introduction of Service Tax

- 1999 Formation of Empowered Committee on State VAT

- 2000 Implementation of uniform floor Sales tax rates

- Abolition of tax related incentives granted by States

- 2003 VAT implemented in Haryana in April 2003

- 2004 Significant progress towards CENVAT

- 2005-06 VAT implemented in 26 more states

- 2007 First GST stuffy released By Mr. P. Shome in January

- 2007 F.M. Announces for GST in budget Speech

- 2007 CST phase out starts in April 2007

- 2007 Joint Working Group formed and report submitted

- 2008 EC finalises the view on GST structure in April 2008

- 2009 proposed to be implemented from 1.4.2010

- 2016 bill passed in parliament with amendments

- 2016 proposed to be implemented from 1.4.2017

\section{DEMERITS OF INDIRECT TAXES}

1) High Cost of Collection- Indirect Taxes fails to satisfy the principle of economy. The Government has to set up elaborate machinery to administer indirect taxes. Therefore, cost of tax collection per unit of revenue raised is generally higher in case of most of indirect taxes.

2) Increase income inequalities- Generally, the indirect taxes are regressive in nature. The rich and poor have to pay the same rate of indirect taxes on certain commodities of mass consumption. This may further increase income disparities among rich and poor.

3) Affects Consumption- Indirect taxes affects consumption of certain products, for instance a high rate of duty on certain products such as consumer durables may restrict the use of such products. Consumers belonging to middle class group may delay their purchases, or they may not buy the product at all. The reduction in consumption affects the investment and production activities, which in turn hampers economic growth.

4) Lack of social consciousness- Indirect taxes do not create any social consciousness as the taxpayers do not feel the burden of taxes they pay. 
5) Uncertainty- Indirect Taxes are often rather uncertain. Taxes on commodities with elastic demand are particularly uncertain, since quantity demanded will greatly affect as prices go up due to imposition of tax. In fact a higher rate of tax on a particular commodity may not bring more revenue.

6) Inflationary- The indirect taxes are inflationary in nature. The tax charged on goods and services increase their prices. Therefore, to reduce inflationary pressure, the government may reduce the tax rates, especially on essential items.

7) Possibility of tax evasion- There is a possibility of evasion of indirect taxes as some customers may not pay indirect taxes with the support of sellers. For instance, individuals may purchase items without a bill, and therefore, may not pay Sales Tax or VAT, or may obtain the services without a bill and therefore, evade the service tax.

\section{LIMITATIONS OF EXISTING INDIAN TAXES}

Originally, the taxes on the sale of goods were levied in terms of the respective Sales Tax/Trade Tax enactments and the 'entry of goods' was subject to tax under the respective State Entry Tax enactments and this scenario prevailed till the reform process set in whereupon these levies were replaced by VAT.

The levy of tax on provisioning of services was introduced for the first time in 1994 and has been subjected to persistent vigorous legal challenges. Still lot of services remained uncovered. The need for transition from the Sales Tax /trade structure for taxing commodities to a value added (VAT). However the shift to VAT did not put to an end to cascading realities. This because Parliament has maintained its own VAT model and also the State Legislatures their own, there was no linkage between the two and thus the credit of duties paid on manufacture are not available towards adjustment on duties payable on sale of goods. Input set-off available to the manufacturers. Thus it is evident that the transition to VAT did not remedy the issue of noncreditable duties and the consequent cascading effect requiring further reform in the area and consequently GST arose.

Service tax was introduced in 1994. Current service tax rate is $15 \%$. The scope of service tax has since been expanded continuously by subsequent Finance Acts and now nearly 109 services are covered. But there are many service sectors which are out of purview of Central Government which can generate more revenue to Government, despite of existence of multiple taxes like Excise, Customs, Education Cess, Surcharge, VAT, Service Tax etc. GDP of India is much lower than GDP of countries like USA, China and Japan. India has miles to go to achieve this level.

Therefore, the Indirect Taxes are therefore urgently required to be rationalized and unified. If the G.S.T. is introduced it would certainly increase the volume of tax collection. The implementation of GST would ensure that India provides a tax regime that is almost similar to the rest of the world. It will also improve the international cost competitiveness of native goods and services.

\begin{tabular}{|l|} 
The shortcomings can be summarized as under: \\
\begin{tabular}{|c|c|}
\hline & Multiple taxes \\
\hline - & Lack of uniformity in tax rates \\
\hline - & Enhance cost of compliance/ cost of collection \\
\hline
\end{tabular}
\end{tabular}




\begin{tabular}{|ll|}
\hline - & Tax cascading \\
\hline - & Litigation fatigue \\
\hline - & Frequent law changes \\
\hline - & Reduced export competitiveness \\
\hline - & Supply chain overheads \\
\hline - & Narrow base \\
\hline - & Blurring distinction between goods and services \\
\hline
\end{tabular}

\section{RESEARCH METHODOLOGY}

The paper is purely based on secondary data. The data is collected from different newspapers, magazines and reputed journals as it is a study on the latest amendment of constitution i.e. $122^{\text {nd }}$ amendment of Goods and Services Tax. This study is done to study the effect of new amendment on the prices of products and how it is going to reduce the tax burden on the consumers.

\section{GOODS AND SERVICES TAX}

Goods and Service tax would be a comprehensive indirect tax on manufacture, sales and consumption of goods and services in India, to replace taxes levied by central and state governments. GST world be levied and collected at each stage of sale or purchase of goods or services based on the input credit method. Amalgamating several central and State taxes into a single tax would mitigate the double taxation, facilitating a common national market. The introduction of GST would be a significant step in the reform of indirect taxation in India.

\section{NEED FOR GST MODEL IN INDIA}

- The proposed GST seems to be based on the above principle. Following are the supporting reasons to adopt GST

- Present system allows for multiplicity of taxes, the introduction of GST is likely to rationalize it.

- Many areas of Services which are untaxed, after the introduction of GST they will also get covered.

- GST will help to avoid distortions caused by present complex tax structure and will help in development of a common national market.

- Existing taxes i.e. Excise, VAT, CST, Entry Tax have the cascading effects of taxes. Therefore, we end up in paying tax on tax. GST will replace existing taxes.

- GST will lead to credit availability on interstate purchases and reduction in compliance requirements.

- Introducing GST will do more than simply redistribute the tax burden from one sector or Group in the economy to another.

- Achieves, uniformity of taxes across the territory, regardless of place of manufacture or distribution

- Provides, greater certainty and transparency of taxes

- Ensure tax compliance across the country

- GST will avoid double taxation to some extent. 
- The implementation of GST would ensure that India provides a tax regime that is almost similar to the rest of world. It will also improve the International cost competitiveness of native Goods and Services.

- GST will provide unbiased tax structure that is neutral to business processes and geographical locations.

- If the Goods and Service Tax is implemented in the true spirit, it will have many positives for the stakeholders and will lead to a better tax environment.

\section{INTRODUCTION OF GST}

Introduction of the Value Added Tax (VAT) at the Central and the State level has been considered to be a major step - an important step forward - in the globe of indirect tax reforms in India. If the VAT is a major improvement over the pre-existing Central excise duty at the national level and the sales tax system at the State level, then the Goods and Services Tax (GST) will indeed be an additional important perfection - the next logical step - towards a widespread indirect tax reforms in the country. Initially, it was conceptualized that there would be a national level goods and services tax, however, with the release of First Discussion Paper by the Empowered Committee of the State Finance Ministers on 10.11.2009, it has been made clear that there would be a "Dual GST" in India, taxation power - both by the Centre and the State to levy the taxes on the Goods and Services. Almost 150 countries have introduced GST in some form. While countries such as Singapore and New Zealand tax virtually everything at a single rate, Indonesia has five positive rates, a zero rate and over 30 categories of exemptions. In China, GST applies only to goods and the provision of repairs, replacement and processing services. GST rates of some countries are given below:

\begin{tabular}{|ll|}
\hline Country & Current rate of GST \\
\hline Australia & $10 \%$ \\
\hline France & $20 \%$ \\
\hline Canada & $5 \%$ \\
\hline Germany & $19 \%$ \\
\hline Egypt & $10 \%$ \\
\hline Japan & $8 \%$ \\
\hline Singapore & $7 \%$ \\
\hline New Zealand & $15 \%$ \\
\hline
\end{tabular}

World over in almost 150 countries there is GST or VAT, which means tax on goods and services. Under the GST scheme, no distinction is made between goods and services for levying of tax. In other words, goods and services attract the same rate of tax. GST is a multi-tier tax where ultimate burden of tax fall on the consumer of goods/ services. It is called as value added tax because at every stage, tax is being paid on the value addition. Under the GST scheme, a person who was liable to pay tax on his output, whether for provision of service or sale of goods, is entitled to get input tax credit (ITC) on the tax paid on its inputs.

- GST is not going to be an additional new tax but will replace other taxes.

- GST is a simple, transparent, and efficient system of indirect taxation.

- The system facilitates taxation of goods and services in an integrated manner. 
- It is a comprehensive value added tax on the supply and consumption of goods and services in an economy.

- GST is levied at every stage of production-distribution chain with applicable set-offs. GST is basically a tax on final consumption.

- In simple terms, GST may be defined as a tax on goods and services, which is leviable at each point of sale or provision of service, in which at the time of sale of goods or providing services the seller or service provider may claim input credit of tax which he has paid while purchasing the goods or procuring the services.

- It will help in eliminating tax induced economic distortions and gives boost to the economy.

- The compliance and administrative cost will be much lower.

On indirect tax front, India is all set to usher into the era of all new tax called 'Goods and Service Tax' which will bring in India at par with over 140 developed Nations of the world. It is going to be the biggest tax reform ever introduced in Independent India.

\section{WORKING OF GST}

The tax will be imposed on the goods and services and will be vatable i.e. at each stage of manufacturing or selling taxes paid earlier can be set off against taxes to be paid at that point of manufacture or sale. Keeping in mind the federal structure of India, there will be two components of GST-Central GST and State GST. Both Centre and State will simultaneously levy GST across the value chain. No cross utilization of credit will be permitted. Thus GST will be a dual tax. For example if the tax on a product is $20 \%, 10 \%$ will be payable to state as its GST and $10 \%$ to centre as its share of GST, the central government will also have to share some part of revenue according to the centre state devolution formula to be decided by the Finance Commission.

To explain the nature of its vatability, an example will suffice. Let us take an example of mobile phone maker "A". He buys chips from "B" for Rs. 500 on which he pays GST at the rate of 10\% or Rs.50. A also buys the services of software firm for Rs.300 in designing the mobile phone and pays a tax of $15 \%$ or Rs.45. He finally sells the phone for Rs.1200 to wholesaler. While selling it, A has to pay a tax of $20 \%$ of Rs.240 making the final price Rs.1440. However, the firm gets a tax set off for the Rs.95 already paid as tax. So the net tax which A has to pay is Rs.145 (Rs.24095). In case the tax was not vatable the final price would have been higher by Rs.95.

\section{SALIENT FEATURES OF GST BILL}

- The power to make laws in respect of supplies in the course of interstate trade or commerce will be vested only in union govt. states will have the right to levy gst on intra state transactions including on services.

- Centre will levy the IGST on interstate supply of goods and services. Import of goods will be subject to basic custom duty and IGST.

- GST defined as any tax on supply goods and services other than on alcohol for human consumption. 
- Central taxes like cent excise duty, additional excise duty, service tax, additional custom duty and special additional duty and state level taxes like vat, CST, entertainment tax, entry tax, purchase tax, luxury tax and octroi will submit in GST.

- Petroleum and petroleum products i.e. crude, high speed diesel, motor spirit, aviation turbine fuel and natural gas shall be subject to the GST on a date to be notified by the GST Council.

- Provision for removing imposition of entry tax/ octroi across India.

- Entertainment tax, imposed by states on movie, theatre etc. will be subsumed in GST, but taxes on entertainment at panchayat, municipality or district level to continue.

- GST may be levied on the sale of newspapers and advertisements and this would give the govt. access to substantial incremental revenues.

Stamp duties, typically imposed on legal agreements by state, will continue to be levied by the states.

Administration of GST will be the responsibility of GST Council, which will be the apex policy making body for GST. Members of GST Council comprised of central and state ministers in charge of financial portfolio.

\section{BENEFITS OF GST}

1) GST provide comprehensive and wider coverage of input credit setoff, you can use service tax credit for the payment of tax on sale of goods etc.

2) CST will be removed and need not pay. At present there is no input tax credit available for CST.

3) Many indirect taxes in state and central level included by GST, You need to pay a single GST instead of all.

4) Uniformity of tax rates across the states

5) Ensure better compliance due to aggregate tax rate reduces.

6) By reducing the tax burden the competitiveness of Indian products in international market is expected to increase and there by development of the nation.

7) Prices of goods are expected to reduce in the long run as the benefits of less tax burden would be passed on to the consumer.

\section{OBJECTIVES OF GST}

One of the main objectives of GST would be to eliminate the cascading impact of taxes on production and distribution cost of goods and services. The exclusion of cascading effects i.e. tax on tax will significantly improve the competitiveness of original goods and services which leads to beneficial impact to the GDP growth. It is felt that the GST would serve a superior reason to achieve the objective of streamlining indirect tax regime in India which can remove cascading effects in supply chain till the level of final consumers only when all such above mentioned indirect taxes are completely included in GST. It is understood that alcohol, tobacco and petroleum products will not be enclosed by GST as alcohol and tobacco are considered as Sin Goods, and governments do not like to allow free trade on these property. 


\section{CHALLENGES}

\section{1) With respect to Tax Threshold}

The threshold limit for turnover above which GST would be levied will be one area which would have to be strictly looked at. First of all, the threshold limit should not be so low to bother small scale traders and service providers. It also increases the allocation of government resources for such a petty amount of revenue which may be much more costly than the amount of revenue collected. The first impact of setting higher tax threshold would naturally lead to less revenue to the government as the margin of tax base shrinks; second it may have on such small and not so developed states which have set low threshold limit under current VAT regime.

\section{2) With respect to nature of taxes}

The taxes that are generally included in GST would be excise duty, countervailing duty, cess, service tax, and state level VATs among others. Interestingly, there are numerous other states and union taxes that would be still out of GST.

\section{3) With respect to number of enactments of statutes}

There will two types of GST laws, one at a centre level called 'Central GST (CGST)' and the other one at the state level - 'State GST (SGST)'. As there seems to have different tax rates for goods and services at the Central Level and at the State Level, and further division based on necessary and other property based on the need, location, geography and resources of each state.

\section{4) With respect to Rates of taxation}

It is true that a tax rate should be devised in accordance with the state's necessity of funds. Whenever states feel that they need to raise greater revenues to fund the increased expenditure, then, ideally, they should have power to decide how to increase the revenue.

\section{5) With respect to tax management and Infrastructure}

It depends on the states and the union how they are going to make GST a simple one. Success of any tax reform policy or managerial measures depends on the inherent simplifications of the system, which leads to the high conformity with the administrative measures and policies.

\section{OPPORTUNITIES}

\section{1) An end to cascading effects}

This will be the major contribution of GST for the business and commerce. At present, there are different state level and centre level indirect tax levies that are compulsory one after another on the supply chain till the time of its utilization.

\section{2) Growth of Revenue in States and Union}

It is expected that the introduction of GST will increase the tax base but lowers down the tax rates and also removes the multiple point This, will lead to higher amount of revenue to both the states and the union.

\section{3) Reduces transaction costs and unnecessary wastages}


If government works in an efficient mode, it may be also possible that a single registration and single compliance will suffice for both SGST and CGST provided government produces effective IT infrastructure and integration of such infrastructure of states level with the union.

\section{4) Eliminates the multiplicity of taxation}

One of the great advantages that a taxpayer can expect from GST is elimination of multiplicity of taxation. The reduction in the number of taxation applicable in a chain of transaction will help to clean up the current mess that is brought by existing indirect tax laws.

\section{5) One Point Single Tax}

Another feature that GST must hold is it should be 'one point single taxation'. This also gives a lot of comforts and confidence to business community that they would focus on business rather than worrying about other taxation that may crop at later stage. This will help the business community to decide their supply chain, pricing modalities and in the long run helps the consumers being goods competitive as price will no longer be the function of tax components but function of sheer business intelligence and innovation.

\section{6) Reduces average tax burdens}

Under GST mechanism, the cost of tax that consumers have to bear will be certain, and GST would reduce the average tax burdens on the consumers.

\section{7) Reduces the corruption}

It is one of the major problems that India is overwhelmed with. We cannot expect anything substantial unless there exist a political will to root it out. This will be a step towards corruption free Indian Revenue Service.

The duly amended Constitution Amendment Bill for GST ("the Bill"), which was passed by the Rajya Sabha last week, has been cleared by the Lok Sabha unanimously on 8 August 2016.

With this, the Bill has been passed by the Parliament and will now go for Presidential reference and subsequently sent to the States for ratification in their respective legislative assemblies. Atleast half of the States will need to ratify the Bill before the President can give the assent for its enactment.

The Government had moved various amendments, including scrapping of one percent additional tax and providing full compensation to the States for first five years of GST roll-out, in the Bill approved by the Rajya Sabha.

The Prime Minister addressed the members of the Lok Sabha during the passage of the Bill. The States have been requested to take up the Bill for ratification to enable the early implementation of the GST, scheduled to be introduced from 1 April 2017.

Government hopes that the Bills for GST legislation, to be finalised by the GST Council will be passed in the winter session of Parliament and the respective State legislatures.

\section{CONSTITUTIONAL AMENDMENT}


After the passage of the Constitution (122nd Amendment) Bill, 2014 in the Lok Sabha on 6 May 2015, the duly amended Constitution Amendment Bill has been finally cleared unanimously by the Rajya Sabha on 3 August 2016. It thus paves way for implementation of GST, one of the historic and most significant tax reforms in the country, post- independence.

The key amendments carried out in the Bill during the course of its passage in the Rajya Sabha include:

i. Deletion of $1 \%$ additional tax which had been earlier proposed on all inter-state supply of goods;

ii. Full compensation to the States for first five years towards the losses if any, incurred by the States due to implementation of GST.

iii. Establishing a mechanism for adjudicating any dispute between Centre and States or between the States, arising out of the recommendations of GST Council.

The cap on GST rate, which has yet to be determined, has not been included as a part of the Bill. The Bill will now be sent to Lok Sabha which will approve the amendments and clear it with twothird majority. Through Presidential reference, Bill will be then ratified by at least half the State assemblies, through two-third majority, before it gets President's assent for its enactment.

This will be followed by formation of GST Council within 60 days of enactment, launch of GST Network and framing of Central, State GST Law along with the Law for GST to be levied on supplies in the course of inter-state trade.

Government may take up the Bill for Goods and Services Tax Law possibly in the winter session of the Parliament.

More action will be seen on GST in the coming days, particularly on GST legislation, including administrative and compliance processes, place of supply and other rules. We shall keep you updated on the developments on GST.

\section{MAJOR FEATURES OF $122^{N D}$ CONSTITUTIONAL AMENDMENT}

- Dispensing with the concept of 'declared goods of special importance' under constitution

- Conferring simultaneous power upon Parliament and the state legislatures to make laws governing goods and service tax

- Levy of integrated goods and service tax on inter-state transactions of goods and services

- GST to be levied on all the goods and services except alcoholic liquor for human consumption, petroleum and petroleum products

- Compensation to the states for loss of revenue arising on account of implementation of GST for a period of 5 years

- Creation of GST Council to examine issues related to GST and make recommendations to the Union and the States on parameters like rates, taxes, cesses and surcharges, etc.

- Subsuming of State VAT/Sales Tax, Central Sales Tax, Octroi and Entry Tax, Purchase Tax, Luxury Tax, and Taxes on Lottery, betting and gambling 
Post the passage of the Constitution Amendment Bill in the Rajya Sabha on 3 August 2016, the Revenue Secretary, Mr. Hasmukh Adhia, addressed the press conference, today and outlined the GST road-map, maintaining the target date of 1 April 2017 for roll out of GST.

The entire process has been identified into three broad categories, i.e. Legal framework, IT infra and change management with tentative timeline against each of them. Challenges involved in the process of GST implementation were also highlighted.

Important timelines highlighted in the Road-map are as under:

- Ratification of the Constitution Amendment Bill by 16 States within 30 days

- Presenting all legislative bills in the winter session of the Parliament and the State assemblies

- Constitution of GST Council within 60 days of enactment

- $\quad$ Establish GST Network and States IT back-end by November 2016

- Testing of software with live transactions by January 2017

- Outreach programme as a part of change management to be completed by March 2017

- Software of GST to be ready by December 2016

- VAT/Service Tax/Central Excise to migrate to GST

- Stakeholder consultation to be completed by March 2017

\section{Key challenges indicated are with reference to:}

- GST rate structure

- Calculation of revenue base and the compensation

- List of exemptions

- Consensus on GST Law

- Consensus on threshold limit

- Administrative control over scrutiny cases by Centre and State

- Government seems keen to put all its effort to meet the deadline. Industry Inc need to gear up with the requisite preparation for transitioning into the new unified GST regime.

\section{CONCLUSION}

In conclusion we can say that the introduction of Goods and Service Tax is the most logical step towards a comprehensive taxation system. It is the best way to reduce the cascading effect or the double taxation in many foods and services. GST is leviable on all supply of goods and provision of services as well combination thereof. All sectors of economy whether the industry, business including Government departments and service sector shall have to bear impact of GST. This is one of the biggest taxation reforms. Experts say that GST is likely to improve tax collections and Boost India's economic development by breaking tax barriers between States and integrating India through a uniform tax rate. Under GST, the taxation burden will be divided equitably between manufacturing and services, through a lower tax rate by increasing the tax base and minimizing exemptions.

\section{REFERENCES}


[1] "An insight of GST in India" by The Institute Of Cost Accountants Of India (October 2015)

[2] Srinivasan Pagaltrivarthi "GST: Analysis, Finding and suggestions” International Tax Research and Analysis Foundation; Occasional Paper 1(December 2015)

[3] G. Raghuram, K.S. Deepa "Goods And Services Tax: The Introduction Process" W.P. No.2015-03-01, March 2015.

[4] "Moving to Goods and Services Tax in India: Impact on India's Growth and International Trade" A report by National Council of Applied Economic Research

[5] Atul Patel, Aurobinda Panda "The Impact of GST on the Indian Tax Scene" SSRN Id: 1868621 (August 2015).

[6] Jayanta Roy Chowdhury "Goods and Services Tax The Roadmap Ahead" Employment News (August 2016) 